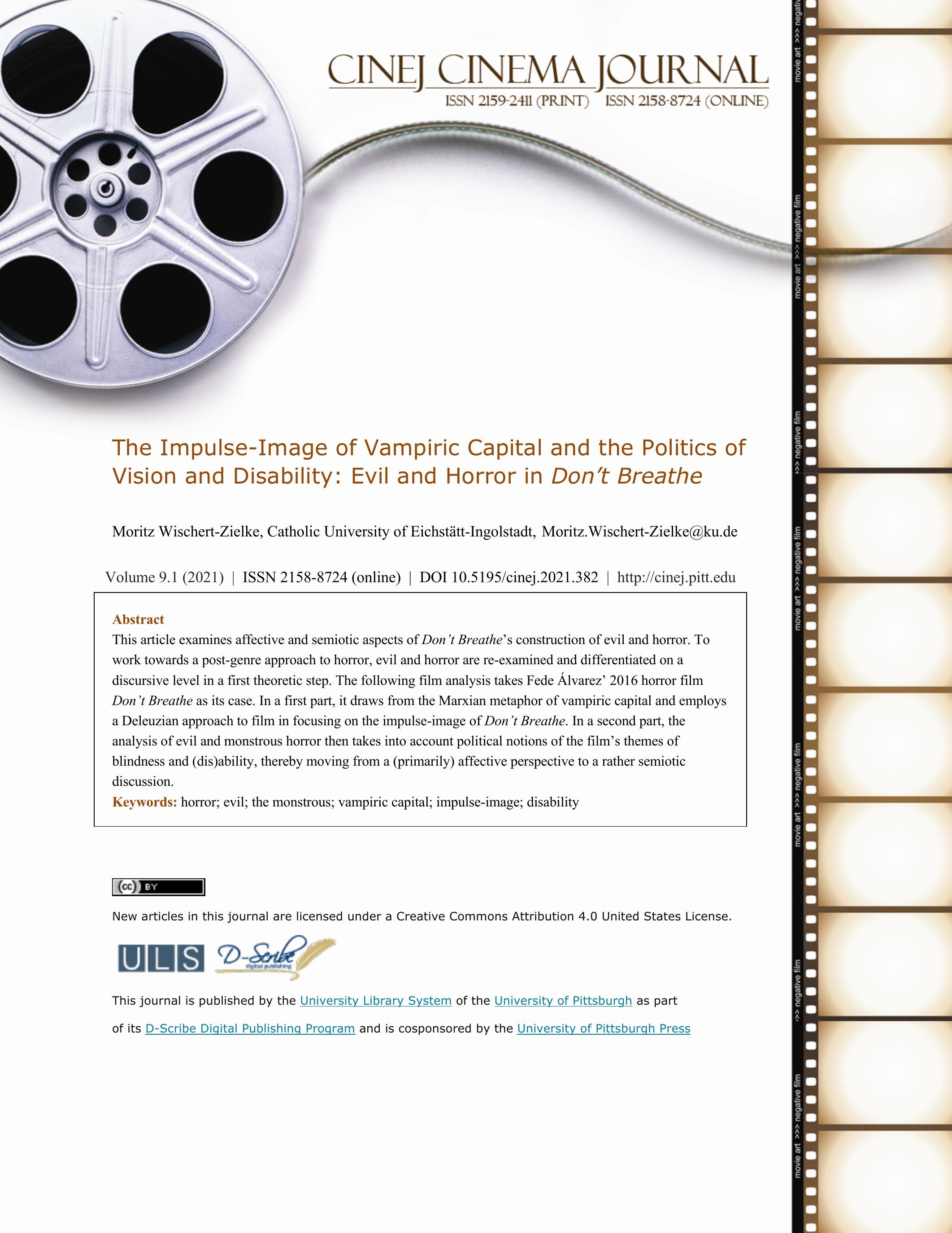




\section{The Impulse-Image of Vampiric Capital and the Politics of Vision and Disability: Evil and Horror in Don't Breathe Moritz Wischert-Zielke}

\section{Introduction}

Most historiographies of horror film have held to the view that "[a] psychic history of culture could be written very efficiently from the morphology of its monsters" (McConnell 1975, 136). Pointing to the subversive potential of these monstrous Others, Cynthia Freeland emphasizes the horror genre's capacity for "subtle reflections on evil" and approaches it primarily as "one very large, popular, ongoing, and accessible body of material for symbolizing evil" $(2000,2)$. Yet, both merely subsuming horror under the cultural reflections on evil and grounding it in a particular type of text (horror film, horror video game, etc.) in a classifying motion seem unsatisfying given said culturally and philosophically subversive potential of monstrous horror.

This article aims to address and differentiate aspects of both evil and horror in the 2016 US horror film Don't Breathe by Fede Álvarez. In a first step, a brief conceptual frame of the discourse of evil and horror is developed which allows a discussion of horror beyond the borders of genre theory. Next, Don't Breathe serves as a recent case of a commercially successful film which exemplifies both subversive potential (de-territorialization) and its accompanying counter-forces of discursive repetitions (re-territorialization) in regard to aspects of horror and evil. The analysis will proceed by moving from a primarily affective perspective in a first section to a primarily 
semiotic in a second. I will draw from the Marxian metaphor of "vampiric capital" and employ a Deleuzian approach to film in focusing on the impulse-image of Don't Breathe. Then, the analysis of evil and monstrous horror will consider political notions of the film's constructions of blindness and (dis)ability.

\section{A Post-Genre Approach to Monstrous Horror: Differentiating Evil and}

\section{Horror}

The concept of evil has a long history in Western philosophy and is tied to what could be approached as the building of intelligible worlds. Already in Plato's privation theory in Timaeus, the narrative makes a great effort to construct the world as "the best of the intelligible things" (1997, 30a). According to Susan Neimann, two events, whose radical impact we name through their places, Lisbon and Auschwitz, have historically shaped the thinking about evil:

Lisbon shocked the eighteenth century as larger and more destructive earthquakes did not move the twentieth. And though the Thirty Years' War was barbaric and ravaging, it did not leave those who lived through it feeling conceptually devastated. Auschwitz did. The difference in response [. . .] lies in the difference between the structures that each era had used to make sense of suffering. The very differences in the nature of the events caused differences in the kinds of shock they produced. Lisbon revealed how remote the world is from the human; Auschwitz revealed the remoteness of humans from themselves. [. . .] After Lisbon, the scope of moral categories contracted. Before Lisbon, they could be applied to the world as a whole; it made sense to call earthquakes evils. Afterward moral categories were confined to one small piece of the world, those human beings who may be able to realize them. Auschwitz raised doubts about the sense in which we apply moral categories at all. 
Platonism and Neoplatonism were paradigmatic for early metaphysical accounts of evil, which Neimann labels "premodern" in their insistence that "reality is not what it seems" (Neimann $2015,203)$. Plato solves the philosophical problem of the existence of evil in maintaining that his "most excellent" (1997, 29a) builder-God is indeed benevolent, but in the position of the almostalmighty he ${ }^{1}$ has to deal with a decisive flaw in his teleologic creation process. Plato assumes a tendency in matter "to set things adrift" (48b) resulting from the dichotomy of soul and matter. Evil as the deviation from a divine model, then, is "never a self-standing metaphysical principle" (Scudieri 2019, 15) in Plato and forms the core of many Christian privation theories after him. From Augustine, Anselm of Canterbury, and Thomas Aquinus to Leibniz's famous claim for the "the best of all possible worlds" $(2007,128)$, evil was taken as a secondary principle. After Lisbon, Kant's categorical imperative related evil to human will, universal law, and thus, exclusively to morality $(1999,60)$. Even where Nietzsche most vehemently disagreed with Kantian conceptions of subjectivity and free will, Nietzsche and Kant both shared a dismissal of evil as a metaphysical problem. Postmetaphysical accounts of evil after Auschwitz were taken up again with Hannah Arendt's efforts to come to grips with both radical $(1955,1102)$ and banal $(2007,371)$ notions of Nazi crimes after WWII.

\footnotetext{
${ }^{1}$ Plato uses the male pronoun.
} 
Examining these changing ways of speaking about evil, sociologist Alexander takes up the example of the Holocaust to propose a cultural sociology of evil. His analysis of historical sources points to an "initial failure of identification" $(2003,30)$ with the Jewish victims. Since the Holocaust was initially regarded not as a supersymbol of inhumanity but a war crime among many, he argues that "[b]ecoming evil is a matter, first and foremost, of representation" (32). He proposes a threefold structure for the social construction of evil: "the nature of what was seen and discovered had to be coded, weighted, and narrated" (33). In order to institutionalize evil socially, it has to be experienced in scandals, moral panics, (public) punishments, wars, but also news reports, novels, films, (video) games, etc. Only through these processes, Alexander claims, can the possibility of binary evaluations and thus of building intelligible worlds be maintained at all.

Akin to Alexander's criticism that evil has been a neglected category in the social sciences, this essay makes the same claim for horror. The majority of approaches towards horror in academic contexts regards it as a particular genre. Exceptionally influential was Noël Carroll's approach in The Philosophy of Horror. Drawing primarily from cognitivist reader-response theory and narratology, he made the effort of grouping various novels, short stories, films, operas, musicals, pieces of fine art, and radio/TV programs together referring to them as "art-horror". The common 
feature he constructs around them is the capacity of their monster figures to effect art-horror, which

he describes as a particular emotion in the audience:

$[\mathrm{I}] \mathrm{t}$ is an emotion whose contours are reflected in the emotional responses of the positive human characters to the monsters in works of horror. I am also presuming that art-horror is an occurrent emotional state, like a flash of anger, rather than a dispositional emotional state, such as undying envy. An occurrent emotional state has both physical and cognitive dimensions. Broadly speaking, the physical dimension of an emotion is a matter of felt agitation. Specifically, the physical dimension is a sensation or a feeling. An emotion, that is, involves some kind of stirring, perturbation, or arrest physiologically registered by an increase in heartbeat, respiration, or the like.

1990,24

By referring to art-horror as an emotion, Carroll puts emphasis on the origin of the term,

the "Latin 'horrere' - to stand on end (as hair standing on end) or to bristle - and the old French 'orror' - to bristle or to shudder" $(1990,24)$. And yet, as a cognitivist, he identifies the cognitive elements of an emotion (both factual and evaluative) to be their distinguishing feature. What is needed for the emotion of art-horror according to Carroll, is a mix of fear (threat) and revulsion (impurity), i.e. in the figure of the monster, "threat is compounded with revulsion, nausea, and disgust" (22).

Expanding Carroll's trend-setting claims, philosopher Paul Santilli prepares a first broad but useful philosophical differentiation of evil and horror. In his essay "Culture, Evil and Horror”, he argues that "[t]he counterpart of culture [. . .] is not nature but horror"; more specifically, "the antithesis of culture is not nature but the unnatural — that is, the monstrosity that does not fit into any categories or names" $(2007,174)$. One way to approach horror outside of a genre approach 
(which draws up a taxonomy of texts), then, is to see it as the undefined Other of culture which escapes or falls through the grid of its categories. From this follows that evil is distinct from horror in that, as Alexander claims, the social construction of evil plays a decisive cultural role in maintaining the possibility for evaluation. Horror, as Santilli points out, is the monstrous and undefined Other of a culture. One way to approach this continuum of how well a cultural matrix grasps a phenomenon could be thought through the Foucauldian idea of discourse.

The poststructuralist Foucauldian idea of discourse points towards "a strongly bounded area of social knowledge, a system of statements within which the world can be known" (Ashcroft 2007, 83). Unlike many earlier notions of the term "discourse" it goes beyond language and towards the sayable, even the knowable. Foucault treats discourses not merely as "groups of signs (signifying elements referring to contents or representations) but as practices that systematically form the objects of which they speak" $(1972,49)$. Discourses are practiced social formations which produce knowledge. This strong concept of discourse emphasizes how the world as we know it cannot consciously be separated from discourse as the latter is the very means by which we bring forth the objects of the world and constitute them within our world view. It is in this sense that Foucault maintains that "power and knowledge directly imply one another" as there is neither a "power relation without the correlative constitution of a field of knowledge, nor any knowledge 
that does not presuppose and constitute at the same time power relations" $(1977,27)$. As long as there is a practical consensus as to what the categories "unemployed", "female" or "black" entail, people can be known and governed through them - bodies can be marked as this or that, they can be produced in a social field.

The cultural construction of evil and social Others as Alexander approaches it (processes of coding, weighing, and narrating) can be considered embedded in a discourse of evil which it simultaneously shapes and in whose coordinates it develops. Monstrous horror, however, points to the experience of a cultural crisis of categories, as Santilli stresses $(2007,174)$. Neimann, who does not differentiate between evil and horror herself, is right to pay close attention to moments of cultural crisis. She holds that both Lisbon and Auschwitz "created boundaries between what could and what could not be thought" $(2015,239)$. From a discursive perspective on evil and horror, such unconscious boundaries are, of course, always present and in flux; it is only in cases of crisis that they shift noticeably when the relationship between evil and horror, the discursive borderline, is moved on a wider scale.

As current monster studies detail, monstrous horror itself has a manifold and rich discursive presence in academic and non-academic social practices. As Cohen puts it, monsters are "a mode of cultural discourse" (1996, viii) in that they are "drawn from a shared vocabulary" and belong to bodies "both particular as well as transhistorical" $(2013,451)$. Feminist and posthuman criticism 
testifies to the ambivalent cultural powers of such hybridity as found in Donna Haraway's cyborg, "a creature of social reality as well as a creature of fiction" $(2016,5)$. However, monstrous horror also points towards the non-signifiable, the non-domesticated, what one could call the extradiscursive.

As Santilli observes in his reading of Heidegger, horror has an ontological dimension. Heideggerian Angst does not require an object such as Carroll's monsters of art-horror; Angst is a fear of being in the world itself: "[d]as Wovor der Angst ist das In-der-Welt-sein als solches"2 $(1967,186)$. There is an experience of the alien nature of existence in which everyday familiarity collapses: “[d]ie alltägliche Vertrautheit bricht in sich zusammen” (189). In Levinas' idea of the "il y a", the "there is", however, horror attains a pre-ontological meaning signifying "an existing that occurs without us, without a subject, an existing without existents" (1967, 45-6). This pure and anonymous existing, as in the endless night which blurs all shapes beyond self and other or the experience of insomnia, an "immortality from which one cannot escape" (48), Levinas calls horror: "[t]he rustling of the there is [sic] is horror" $(1989,32)$. Contrary to Heideggerian Angst, in the horror of being, the categories "world" and "self", just like the very distinctions between “interior" and "exterior", break down: "[w]hat we call the I is itself submerged by the night,

2 "That in the face of which one has anxiety is Being-in-the-world as such" (my translation). 
invaded, depersonalized, stifled by it" (31). Moreover, Kristeva's ideas on the abject in Powers of Horror evokes the pre-ontological capacity of what is not yet constituted as an object on the border of the process of subjectification to "disturb identity, system, order" $(1982,4)$. Deleuze's monstrous difference beneath the thinking of identity can be considered a further example (1994, 29). In these thinkers, the pre-ontological powers of monstrous horror testify to an extra-discursive presence which, like Deleuze's difference, we cannot name or think.

In summary, one way of differentiating evil and horror is through their relation as a discursive border. The discourse of evil serves a key normative role in maintaining the possibility for cultural evaluation. Monstrous horror includes aspects both discursive (cultural reflections on and reworkings of the limits of discourse) and extra-discursive, i.e. those not representable in discourse. Following Alexa Wright's discussion of the monstrous in the human, horror joins notions of monstrousness which "encapsulates the impossible, [. . .] unspeakable and even unthinkable qualities that lie at the periphery of human identity" and its effect and cause, monstrosity, "the tangible means by which the unspeakable and threatening force of the monstrous is brought into being" $(2013,3)$.

Film, including but not exclusive to what people call "horror film", plays an essential role in the discourses of evil and monstrous horror. The compelling and classic case of William Friedkin's The Exorcist (1973), only after whose release “countless people were convinced that 
they themselves, or perhaps a loved one, were suffering from demonic affliction" (Cuneo 2001, 9), exemplifies this. More recent examples can be found in films exploring the potential of horror and evil together with such themes as gender and motherhood (The Babadook, Hereditary, The Witch,), mental illness (Midsommar, Joker, The Babadook), and race/racism (Get Out, Us). Taken as a prime sight/site of negotiating evil and horror, the visual regime of cinema will in the following be approached through an analysis of the 2016 film Don't Breathe by Fede Álvarez.

The plot of the film is simple: as a way of escaping the economic woes of their milieu, three amateur burglars break into the house of a blind army veteran to take the money he had received as compensation for his daughter's death in a car accident. Since the "Blind Man", as the films labels him, turns out to be more than able-bodied and as sinister as dangerous, a fight for money and to the death begins. To first account for the affective dynamics and circles the film engages in, I will relate the cinematic experience of Don't Breathe to Marx's metaphor of "vampiric capital" and Deleuze's impulse-image in the following section. In the latter, the construction of monstrous horror and evil against the background of the framework drawn up here urges a closer examination together with the discourse of disability. 


\section{Capitalist Compulsions and the Impulse-Image in Don't Breathe}

If money, according to Augier, "comes into the world with a congenital blood stain on one cheek", capital comes dripping from head to foot, from every pore, with blood and dirt.

Marx 2010, 748

In Marx's work, a great many quotations like the foregoing metaphorically link the movement of capital to the flow of blood. Already in his Economic Manuscripts Marx compares "money to blood" $(1986,99)$. Linked to the idea of "flow" $(2010,173)$ or "ebbing and flowing" (655), in volume I of Capital we find the processes of consumption and unlimited "sucking-in" Marx speaks of "Einsaugung von fremder Arbeit" (1962, 329 emphasis added) in more than 50 cases in the German original of the first volume of Capital alone. Beyond Capital, Neocleous describes a "vampire metaphor" $(2005,36)$ running like a thread through all Marx's many writings. Undead but feasting on the living, Marx's idea of monstrous capital appears "vampire-like, only liv[ing] by sucking living labour" $(2010,240)$. Discussing the length of the workday, Marx speaks of "vampire thirst for the living blood of labour" (263) and speaking of institutional child labor he refers to "bloodsucking institutions" (493). In these uses of the metaphor, the gist is based on an assumed link between the vampiric desire for blood and capital's desire for accumulation. As the social relationship which capital constitutes and repeatedly "performs" is, furthermore, materialized and naturalized in the commodity and its fetish ("the mystical character of commodities" [82]), vampiric capital itself appears to compulsively act on its own assuming an 
"automatically active character" (164). This manmade but nevertheless real, objective, and "felt" capitalist compulsion points to the violence of machinic drives, to the flows of money, blood, and adrenaline, i.e. the hypnotic affection of bodies and their pulses, and to the cinematic experience of a Deleuzian impulse-image which I trace in Don't Breathe.

With the opening shot, the film already and quite literally "sucks" the audience "in" as the camera movement in the aerial shot of a suburban area (Álvarez 2016, 1:01) escapes the impression of a slow zoom and rather turns into a tracking shot of two figures on the street. The camera comes closer, a police siren is heard in the distance (1:27). A sound effect gradually fades in priming us about some yet undefined danger radiating from the camera's object of desire (1:39) until we can make out one body dragging another behind them by their blond hair. "Her" blond hair, we realize. Yet, the following cut to a low-angle medium shot still does not give away the faces of the two (1:56). Cut to the title screen. Immediately from the opening sequence, it is clear that the film breaks with the "sensory-motor-schema" (Deleuze 1997a, 155) of a linear progression from situation (perception) to a changed situation through an intermediary action. As I will show, however, it does not do so by attempting to create more direct images of time (as in dreams, visions etc.) but by moving "below" movement, i.e. by attempting to show what makes us (as characters, as audience but also as film) move. 
After the title screen, the camera introduces us to the three main characters - Alex, Rocky, and Money - through a montage of one of their raids (Álvarez 2016, 2:46). The three make a living by breaking into the better-off mansions in Detroit, a place the characters feel "everybody's leaving" (3:54). We get perception-images of warehouses (5:32), industrial landscapes (7:44), and, especially later, the even more run-down and deserted parts of the city which are described as a "ghost town" (6:29). ${ }^{3}$ When Alex learns about the possible ticket out of their milieu, the "six figure settlement" (8:26) a "Blind Man" allegedly keeps in his home, the film cross cuts this with the trailer home of Rocky's family. Metal scrap and bicycle skeletons in front, crime TV shows, cigarettes, alcohol, and the svastika tattoo of her mother's unemployed boyfriend inside all give the impression of a toxic environment for her younger sister (9:04). Rocky teaches her the lesson of this home: "some things you can't change, baby, no matter how unfair they are" (9:30). Yet, the two make the promise of leaving and dream of the utopian beaches of California - just one more raid. Money is what permits and denies the social mobility of the characters in this world. The flow of capital translates into the flow of bodies. As in Marx, the characters can be seen as "personifications of economic categories" $(2010,10)$. In the position of the worker, whose freedom carries the "double sense" (705) of being free of capital and legally free (and forced) to sell their

\footnotetext{
${ }^{3}$ The film locates the house of the "Blind Man" in Buena Vista St. (translating to "good view") which is situated in Russell Woods, Detroit, Michigan in real life. The website "Areavibes.com" gives residents of the Russell Woods area a one-in-nine chance of being a victim of crime (AreaVibes Inc. 2020).
} 
work, Alex, Rocky, and Money chose to risk the latter sense of freedom to remedy the former.

Even more radically than the worker, the criminal in their abject amorality embodies the hunger

for capital and money. Economically, they act as vampire figures roaming the nights to suck up

what flows they can get. Yet, it is less an action but an acting-on-compulsion, as "the immanent laws of capitalist production [are] felt by each individual capitalist, as external coercive laws" (588). The capitalist symbol, the dollar sign, marks the skin of the character of the same name (Álvarez 2016, 10:36) giving an image of the "magic of money" (Marx 2010, 103) which follows from capitalist "fetishism" (83). In the manner of Marx who pictures the individual no longer as "free agent" (306) but rather speaks of drives and impulses (e.g. 241), Don't Breathe is dominated by images which do not reach the level of the Deleuzian action-image. Particularly where they focus on the main setting, the house of the "Blind Man," the images can be described as impulseimages.

In Cinema I, Deleuze situates the impulse-image between action-image and affectionimage, no longer affect, not yet action: the “"degenerate' affect, or the 'embryonic' action” (1997a, 123). What for the affection-image was the pair "any-space-whatever/affect" and for the actionimage would be "milieu/modes of behavior" here consists of "Originary Worlds/Elementary Impulses" (123). The change of setting from the milieu of the landscapes of Detroit, localizable, 
identified, and individualized in space and time, to the inside of the house of the "Blind Man" exemplifies this. The space of night introduces heavy shadows to the close-up of the face (Álvarez 2016, 18:32). The parts of the backgrounds we can discern from the prevailing dark vaguely resemble a house, doors, walls, furniture. However, at the same time, the elements de-actualize into a virtual space, the any-space-whatever, which has become an originary world, pure background "recognisable by its formless character" (Deleuze 1997a, 123). In the course of the film even the little light which was left is taken away as the "Blind Man" switches off the power in the house (Álvarez 2016, 46:57). What was pure background before essentially turns into the black screen, the space of a hunted consciousness out of touch with a here and now reaching out for its fetish. This is how Deleuze describes the impulse: "the energy which seizes fragments in the originary world "(Deleuze 1997a, 124). In this sense, the film shows what makes move, the world of forces, the drive, the impulse between affect and action. In the second and major part of the film, there is merely one single real conversation (which the second part of this essay discusses). Rather than words, what dominates and causes the flow of movements is experienced (by the characters and the audience) as an intense oscillation between affect and a compressed violence, between the excessive release of neurotransmitters and the following sharpening of the senses, a back-and-forth of embryonic movements which never reach the individuation of actions, in short: a tide of compulsion and adrenalin. 
On screen, the impulse-images find a rhythm of movement, of image and sound, not unlike the beating heart of the body of the audience or the metric foot of the iamb: an unstressed element is followed by a stressed element in a continuous series of progression which in its advance gives the impression of a poetics of capitalist compulsion. In terms of cinematic techniques, mostly, an affection-image is broken up by an excess or micro-climax, an incurving of the universe which does not give rise to a final release of tension. The former element can vary greatly in length and intensity. In one scene, the "Blind Man" is about to take away the body of Money, who he shot, while - unbeknownst to him - Alex and Rocky stand nearby trying to remain unnoticed (Álvarez 2016, 36:00). A creaky floorboard gives their presence away and the killer aims a gun into the direction of the sound (36:29). The faces of Alex and Rocky are shown in a medium shot from the implied point of view of the "Blind Man" with his arm aiming the gun at them protruding into the frame. A couple of seconds he listens and aims around the room while their faces combine their reflecting capacity with the micro expressive power which together form the affection-image. Then the abrupt shock which releases some of the build-up tension: the phone on the ground rings and the gun shot immediately doubles the startling noise (36:58). This second function which contrasts the preceding affective moment is often performed by a technique stemming from horror video games, the "jump scare" (Hart 2019, 59). This technique effects a quick and convulsive shock to 
the perception of a character and the audience by either rapidly flashing a visual difference, extremely quick or unexpected movements, and/or presenting auditory noises and screams which aim at the acoustic pain threshold of the viewer (a flooding of senses). Rather than focusing on the overall atmosphere, the jump scare technique aims directly at the nervous system and bodily reflexes to recreate the physiologic state of the hunted or driven characters on screen for the audience.

In Don't Breathe, this microstructure of affection image and jump scare is lined up more than a dozen times. When the characters enter the originary world of the house, Rocky is startled first (Álvarez 2016, 23:52) - an original affective model. Here it is only Money who unexpectedly says something out loud (auditory micro-climax) whereupon the camera gives a close-up of Rocky shrieking, wincing, then exhaling and showing relief. Her body primes the audience for the rhythm of tension and partial relaxation which is about to go on for over an hour. While singular moments are being charged with affect by high feedbacked noises (20:24), rhythmic almost abstract sound effects create tension throughout giving the impression of a nonhuman pulse, the pulse of pulse - 


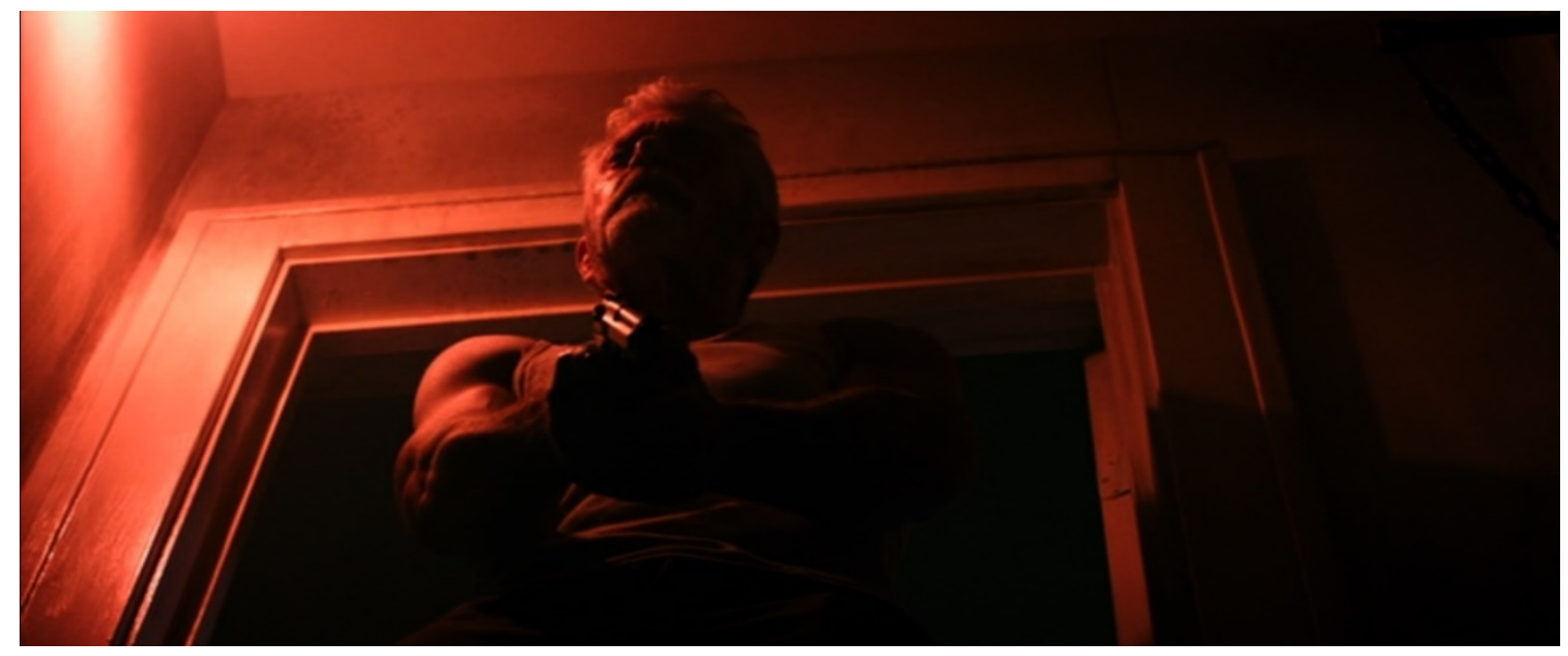

Figure 1. Ground Level Shot of the "Blind Man" - Color as Affect in the Impulse-Image (51:58).

the pulse of the impulse-image itself (28:43). Visually, the characters rush and stagger through almost completely black screens or highly affective colors: blue and green faces in the light of mobile phones (31:26), a red basement light (41:58), and a blue room upstairs (51:09) - in these scenes it is not the color which charges the aura of a place, setting, or props but it is the any-spacewhatever which turns into color. Not affect (as signified) is expressed or associated through the use of a signifying color but "[c]olour is on the contrary the affect itself" (Deleuze 1997a, 118). As contra-points and jump scares a great variety of movements and sounds may function: the "Blind Man” unexpectedly waking up and rising in bed (Álvarez 2016, 22:54), gunshots and fights $(27: 31 ; 1: 10: 13)$, characters appearing abruptly $(29: 59)$, doors being opened or rattled right in the moment when characters are about to open them $(35: 22,50: 52)$. In the basement, the hidden girl actually does "jump" at the characters (40:12) just like the dog later jumps at the car (1:12:20). 
Where there is not already a loud sound effect due to movements etc., accompanying effects are added (thus even sitting up in bed makes a bell sound).

Not unlike the style of the free indirect discourse, the semi-subjective camera mostly captures the affect and shock the characters themselves feel. This is sometimes heightened by the slow motion effect which lets us, too, perform the incurving of the universe according to the unique perception of the individual (25:25). However, at 29:59, Alex is completely unaware of the threat behind him. The added sound which is heard when the killer suddenly comes around the corner and only barely misses the unknowing character is added purely for the audience's perception there is no other focalizer for it. The mirroring effect of character and audience can thus be broken up to reveal the artificiality and purposefulness of the composition of the shot. For a glimpse, the audience and the film both seem quite aware of each other. This awareness of the other party introduces a kind of game-effect to the experience of viewing the film. At 48:41, the film purposefully employs a retarding moment before the jump scare is exercised: it is not the killer but Alex who stumbles into Rocky. The body of the audience is put in the same cat-and-mouse game, the same adrenaline excesses the impulse-image gives rise to. The extremely long periods of silence in the basement (47:50), for example, further put emphasis on the expectation of a jump scare, the expectation of a particular horror audience. 
In the manner of addressing anticipated expectations of the audience, Don't Breathe can

finally be said to reveal and exercise its fetish, the mystical impulse in the capitalist world on another level. As was shown, the audience engages with the film in the realms of affect and impulse rather than semiotics and language. The vampiric drives of the characters (for nourishment, death, offspring, survival, capital) are reexperienced in the viewing of the film but even performed by the film in turn in its attempt to be successful among audiences financially. Deleuze puts the point as

\section{follows in Cinema 2:}

The cinema as art itself lives in a direct relation with a permanent plot [complot], an international conspiracy which conditions it from within, as the most intimate and most indispensable enemy. This conspiracy is that of money; what defines industrial art is not mechanical reproduction but the internalized relation with money. The only rejoinder to the harsh law of cinema - a minute of image which costs a day of collective workis Fellini's: 'When there is no more money left, the film will be finished.' Money is the obverse of all the images that the cinema shows and sets in place, so that films about money are already, if implicitly, films within the film or about the film.

Deleuze 1997b, 77

Movement and time themselves find their equation in capital on screen and involve the audience in affective circles of exchange and flow. Making felt the restlessness and wickedness of monstrous capital itself which underlies any atomistic movement and haunts any atom, Don't Breathe induces a "becoming-vampire" which reveals in its succumbing to a parasitic impulse the cinema in the cinema as world and the film in the film as money. 


\section{4. (De-)Constructions of Evil and Horror: The Politics of Vision and Disability}

In its manner of coding the very categories by which we live (value, work, freedom, identity) but also doing so in the practices of the everyday which obscure its mechanisms, capital appears as an unconscious Other, omnipresent and objective but also obscured and haunting. Marx repeatedly puts emphasis on this spectral quality of capital: "The intermediate steps of the process vanish in the result and leave no trace behind" $(2010,103)$. In the Marxian analysis, then, capital appears as monstrous in its discursive presence which strives to code everything which fuels it but nevertheless escapes its own categories. From this admittedly idiosyncratic point of view, Marx is a key thinker of horror because he aimed at the limits of discourses. If Don't Breathe (re)creates and (re)produces capitalist compulsions on the level of impulse and affect as I have argued in the foregoing section, what can be said about its practices of (de)constructing evil and horror on a semiotic level?

Let us reconsider the core elements of the plot: the film takes as its protagonists three smalltime criminals and narrates their attempts at fleeing the social milieu of their homes as a struggle for independence. With the poverty of Rocky's family, the film shows us, there come standstill and decay for the family: hunger, drugs, emotional cruelty, and even Nazism. The background story of "The Blind Man" later reveals the same criticism: "Rich girls don't go to jail" (Álvarez 2016, 1:02:24). The implication is that the inequality of the distribution of capital is an obvious 
moral evil in a world which has long left behind the appearance of a Leibnizian "best of all possible worlds" (Leibniz 2007, 128). As criminals, however, the protagonists have also long left behind the collectivist moral principles of a Kantian imperative (Kant 1999, 60). To make the narration of its world intelligible, Don't Breathe thus relies on "coding" the evils of capitalism as a moral evil and "weighing" it against the moral evil of crime (Alexander 2003, 33). The latter, in turn, appears as a justified project of emancipation. As the film moves to its main set, though, a moral evil of another kind appears and is weighed as even worse: in the basement of their assumed victim, there is a chained-up woman kept as prisoner to conceive the child of the "Blind Man" as a punishment for killing his daughter in a car accident. The "real" weighing of evil, then, contrasts the standpoint of Rocky with the antagonist's condemning the latter on moral grounds. During the only conversation in the latter half of the film, Rocky starts to pray offering the account of a metaphysical conception of the world and evil (Álvarez 2016, 1:05:40). In the manner of theodicy, the act of prayer in this scene puts into question not the omnipotence but the benevolence of God which Rocky appeals to. The antagonist's account of evil, on the other side, is clearly postmetaphysical: "there's no God. It's a joke. It's a bad joke. You tell me what God would allow this" (1:05:42). The obvious discursive echo here is the cliché of Nietzsche's often misunderstood claim "God is dead!" $(1974,181)$. And indeed, the "Blind Man" seems to radically reject a Kantian 
agent tied to the idea of universal law: "There is nothing a man cannot do once he accepts the fact that there is no God" (Álvarez 2016, 1:07:08). However, he justifies murder, kidnapping, and rape through the concept of revenge and employs a rhetoric which still holds "accountable" (1:03:29) and claims these acts to be "fair" (1:02:46). His antagonistic account of evil seems lost in the torn down pillars of metaphysics and succumbs to nihilism and the concept of revenge. Clashing with the Nietzschean idea of the eternal return, the antagonist's postmetaphysical account is constructed as an impairment of will, the inability to move on: “'It was': thus is called the will's gnashing of teeth and loneliest misery. Impotent against that which has been - it is an angry spectator of everything past" (Nietzsche 2006, 111). While there is a subtext of an anti-capitalist critique, Don't Breathe, in sum, codes, weighs, and narrates as its greatest evil an extreme moral degeneration which is associated with the loss of metaphysics. This essentially conservative idea of an immoral Other which has lost God, however, is furthermore narrated through and together with other discursive images which tie into the construction of a monstrous body, the discourse of disability, and a particularly visual regime of the power of normalcy.

Several discursive images are used to help code the avatar of monstrous capitalism, the character of the old man. He is first described as an "army vet loner" (Álvarez 2016, 6:22). His many scars visually imply trauma and the ready-to-use guns hidden under the bed and around the house together with the multiple door locks give the impression of a paranoid ex-soldier, a 
personification of the US war machine. In addition, the eugenic but finally impotent dream of fatherhood and his violent attempts to take possession of the female body portray him as a figure of capitalist patriarchy and even rape culture. At the end of the film, he manages to "buy" Rocky's silence since the dominant legal codes are on his side. Capitalism, the war machine, and patriarchy are, nevertheless, not the major elements of his characterization. Tellingly, the character is referred to as "The Blind Man" (1:21:02) in the credits.

The "Blind Man" is obviously written as a disabled character. The early buildup of the theme gives us a perception image of him walking his dog with the indexical white cane (13:01). Davis argues that in the social construction of the disabled body, it "presents itself to 'normal' people through two main modalities - function and appearance" (Davis 1995, 29). Money's comment, “Just 'cause he’s blind don’t mean he's a fucking saint, bro” (Álvarez 2016, 13:15), already establishes the idea of blindness as a functional defect together with the shortcomings of its stereotypes. Indeed, some critical potential of the theme of blindness is exercised as the film goes out of its way to invert the trope of the "passive victim stereotype" (Smith 2004, 266). Contrary to the stereotype of the blind person who in one way or the other suffers from what is constructed as a functional "defect", the "Blind Man" reverses this trope by acting resolutely, recklessly, and, with dangerous precision. In his bodily capacity to apply violence, he reverses the 
blind victim stereotype into what Nietzsche's Zarathustra calls "inverse cripples": "human beings who were missing everything except the one thing they have too much of - human beings who are nothing more than one big eye, or one big maw or one big belly or some other big thing" (2006, 109). While it is usually the "possibility of a knowledge-system not grounded in visuality" (Smith 2004, 265) which the blind witness stereotype poses, the "Blind Man" rather exercises an incorporated violence as a mode of the body. Thus, he functions primarily as a calculating and antagonistic source of danger - a simple and affective reversal of the stereotype.

Further mechanisms of the dialectics of function between vision and blindness are explored in the basement scene. When the "Blind Man" turns out the lights, the film cuts to a completely black screen (Álvarez 2016, 46:56). By putting the audience in such an implied state of blindness or impaired vision, the film thus emphasizes the situationality and constructedness of disability. From this point of view, the cinematic techniques, the camera, the frame, and lighting all refer to and comment on social and cultural structures and (in this scene) help to deconstruct the notion of disability as an inherent defect of the body, a fixed attribute of an essentiality of lack. Yet, the film is not able to keep up this anti-visual regime for more than a couple of seconds - the effect of the black screen is quickly replaced by the return of the camera as night vision camera (47:04). Where the black screen still served as a (subjective) perception-image of the protagonists, the camera-eye that sees in the dark rather indicates the visual position of the audience, and on a self-referential 
level, the visual regime of gazes which marks the subjectivity of a mono-eyed (always-disabled and already prosthetic) cinema itself. What becomes apparent is the inability not to see-normative vision always has to return to the screen; cinema is un-able not to see. In addition to this compulsive voyeurism of the normative visual imperative of cinema and its audience, the visual regime of the camera becomes de-naturalized and, at the same time, again reveals the impaired vision of the audience. With the difference of night vision from the human eye, perception becomes uncanny in its reliance on techno-organic, scientific prosthesis and reveals the Enlightenment project of bringing forth an ordered world of objects by fixing them in visual fields. This notion is paired, however, with the idea that the normative gaze of the audience is itself not objective enough - impaired. Hence, in its own discursive monstrousness, the film on a formal level offers insights into the normative politics of the cinematic gaze which struggles to view Otherness outside of the established conventions. These more nuanced scenes, however, also appear in the trailer of the film where they are reduced to a mere equation of blindness with monstrosity once more. While the sentence is cut from the final film, one YouTube trailer has the "Blind Man" say "now you're gonna see what I see" (Sony Pictures India 2016, 0:01) before the screen turns dark. To attract a voyeuristic horror audience, the trailer constructs a monstrous "Other" point of view and thus exploits disability for shock effect in a fetishized spectacle of affect. 
The tendency to

exploit the affective

attraction of a disabled

monster figure is grounded

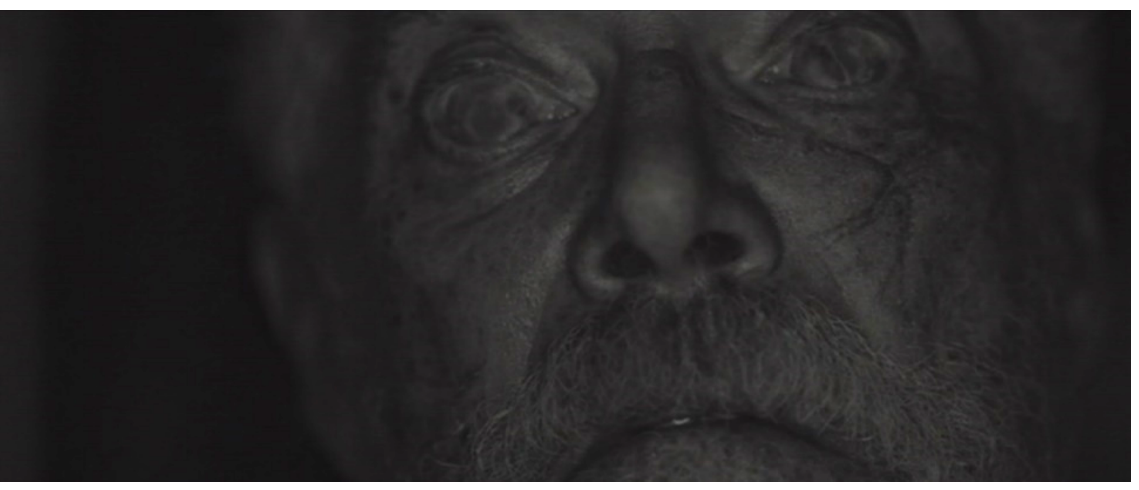

in the process of Figure 2. Close-up of the "Blind Man" in a Jump Scare: the Visualization of

visualization, rather than the

Disability as Construction of Monstrosity (49:05).

idea of function: "[t]he person with disabilities is visualized, brought into a field of vision, and seen as a disabled person" (Davis 1995, 29). In a typical jump scare shot, the "Blind Man" is thus viewed by the night vision camera in an extreme close-up (Álvarez 2016, 49:05). His face is directly brought into vision with its emotionless and cold blind stare contrasted with the brute force of his attempt to strangle Alex. The low contrast of the night vision camera captures the scars on his face and even in his eyes, sudden noises accentuate them after an extreme period of silent buildup. His face is marked as an "Other" face, deadly, relentless, dangerous, and cold. With Mulvey, we can argue for a "to-be-looked-at-ness" $(1975,19)$ of the disabled body. Disability becomes a "specular moment" (Davis 1995, 29) and is thus described by Davis along with sex and violence as one of cinema's most vivid obsessions (171). The cued emotions of the audience here function to construct a monstrous disabled body: "the disabled object is produced or constructed by the strong feelings of repulsion" (29). In the discourse of horror, disability has always been used as a 
key example of the very categories through which thinkers have constructed horror. Freud, for example, thus refers to disabled bodies to coin his notions of das Unheimliche $(1966,257)$. Turning the perspective around, it is possible to argue with Davis that it is rather the construction of the disabled body which helps to construct the ideal of the norm from which it is made to deviate: “disability defines the negative space the body must not occupy" $(1995,175)$. If Mulvey's to-belooked-at-ness refers back to a male gaze, the fetishized quality of the disabled body refers back to a normative gaze of which it is a function.

In general, then, disability in Don't Breathe is intricately associated both with the construction of evil and monstrosity. In the cultural monster's way of acting as a "harbinger of the category crisis" (Cohen 2018, 45), the "Blind Man" blurs the binary pairs of subject (emotion)/object ("thingness"), perpetrator/victim, and even human/animal. The latter aspect is painfully conveyed by having the blind character sniff like an animal predator for his victims in the dark (Álvarez 2016, 38:35). In the visual construction as described above, there is a need to show, to demonstrate the monstrosity of disability which in turn ascribes the qualities of evil and Otherness on to a disabled body. This construction of the disabled body, therefore, involves a particular process of demonst(e)ration. Such ascription of evil to disability discursively manifest in particular stereotypes again: the antagonist perfectly fits the problematic characterization 
Norden labels the "obsessive avenger" $(2007,125)$ in which the disabled character pursues those who he feels have wronged him. In stereotypical images like this, disability gains a function which Mitchell and Snyder approach as "narrative prosthesis" $(2003,47)$ in the discursive reliance on it as stock feature of characterization and as means to construct both norms and characters' deviances from it. While some elements of its text bring subversive moments to the cinematic space, Don't Breathe opportunistically relies on this instrumental and metaphorical function of disability in its construction of evil and monstrosity.

\section{Conclusion}

This essay has made an effort to re-conceptualize horror outside of the tradition of genre theory. A discursive perspective allows for a way of thinking horror which neither equates it with evil nor subjugates it to genre. Taken as a sight/site of discursive construction of evil and the monstrous, the film Don't Breathe was analyzed from an affective and a semiotic perspective. As I have tried to show in a first section, there are multiple ways in which Don't Breathe relates to, comments on, recreates, incorporates, instrumentalizes, and succumbs to capitalist impulses which in impulse-images give rise to a monstrous metaphor of vampiric capital. A latter argument has detailed that those very impulses can also support a critical reversal and a rethinking of 
stereotypical images and clichés, and naturalized perspectives, as some of the subversions of ableist discourses in the narrative show. The construction of monstrosity and evil, however, in its problematic ties to the discourses of normativity and disability, exploits the theme of blindness and codes difference as monstrous in visual regimes which function as catalyzation chambers for some of the rather homophobic elements of its text. Taken for a case of both cinematic and capitalist practices, the film can finally be situated in a field of tension between monstrous metaphors of capital and the normative repetitions of the clichéd thinking of identity they are always at risk of falling back to.

With the case of Don't Breathe one can frame cinema as a site of discursive negotiation of the borders of our thinking which exercises the ambivalent powers of horror even where affective impulses seem to flow "blindly". Its undercurrents are problematic in their stereotypes and the monstrosity they ascribe whereas it also marks a fluid borderline of thought, the edges of the shot. As directors of our own perspectives and narratives, we might grow from allowing difference into our perception-images of the world and the human. Santilli calls this postmodern project a need for an "ethic of personal responsibility and love for that which horrifies, disgusts, and eludes our understanding" $(2007,189)$. 


\section{REFERENCES}

Alexander, J. C. (2003). The meanings of social life: A cultural sociology. Oxford University Press.

Álvarez, F. (2016). Don't breathe. [DVD]. Sony Pictures.

AreaVibes Inc. (2020, Sept). Russel Woods, Detroit, MI Crime. https://www.areavibes.com/detroit$\mathrm{mi} /$ russell+woods/crime/

Arendt, H. (2007). Eichmann in Jerusalem. Ein Bericht von der Banalität des Bösen (B. Granzow, Trans). Piper.

Arendt, H. (1955). Elemente und Ursprünge Totalitärer Herrschaft. Europäische Verlagsanstalt.

Ashcroft, B., Griffiths, G., \& Tiffin, H. (2007). Post-colonial studies: The key concepts. Routledge.

Carroll, N. (1990). The philosophy of horror, or paradoxes of the heart. Routledge.

Cohen, J. J. (2018). Monster culture (seven theses). In A. S. Mittman \& M. Hensel (Eds.), Classic readings on monster theory. Demonstrare volume I (pp. 43-56). ARC Humanities Press.

Cohen, J. J. (2013). Postscript: The promise of monsters. In A. S. Mittmann \& P. J. Dendie (Eds.), The Ashgate research companion to monsters and the monstrous (pp. 449-64). Ashgate.

Cohen, J. J. (1996). Preface: In a time of monsters. In J. J. Cohen (Ed.), Monster theory: Reading culture (pp. vii-xiii). University of Minnesota Press.

Cuneo, M. W. (2001). American exorcism: Expelling demons in the land of plenty. Broadway Books.

Davis, L. J. (1995). Enforcing normalcy. Disability, deafness, and the body. Verso.

Deleuze, G. (1997a). Cinema I. The movement-image (H. Tomlinson \& B. Habberjam, Trans.). University of Minnesota Press.

Deleuze, G. (1997b). Cinema II. The time-image (H. Tomlinson \& R. Galeta, Trans.). U. of Minnesota P.

Deleuze, G. (1994). Difference and repetition (P. Patton, Trans.). Columbia University Press. 
Foucault, M. (1977). Discipline \& punish (A. Sheridan, Trans.) Pantheon Books.

Foucault, M. (1972). The archeology of knowledge \& the discourse on language (S. Smith, Trans.). Pantheon Books.

Freeland, C. A. (2000). The naked and the undead. Evil and the appeal of horror. Westview Press.

Freud, S. (1966). Das Unheimliche. In A. Freud, E. Bibring, W. Hoffer, E. Kris, \& O. Isakower (Eds.), Gesammelte Werke Band 12, Werke aus den Jahren 1917-1920 (pp. 229-68). Fischer Verlag.

Haraway, D. J. (2016). A cyborg manifesto. Science, technology, and socialist-feminism in the late twentieth century. In D. J. Haraway \& C. Wolfe (Eds.), Manifestly Haraway, (pp. 3-90). University of Minnesota Press.

Hart, A. C. (2019). Monstrous forms: Moving image horror across media. Oxford University Press.

Heidegger, M. (1967). Sein und Zeit. Max Niemeyer.

Kant, I. (1999). Grundlegung zur Metaphysik der Sitten (B. Kraft \& D. Schönecker, Eds.). Meiner.

Kristeva, J. (1982). Powers of horror: An essay on abjection (L. S. Roudiez, Trans.). Columbia UP.

Leibniz, G. W. (2007). Theodicy. Essays on the goodness of God, the freedom of Man and the origin of evil (E. M. Huggard, Ed., Trans.). Open Court.

Levinas, E. (1989). There is: Existence without existents. In S. Hand (Ed.), The Levinas reader (pp. 29-36). Basil Blackwell.

Levinas, E. (1967). Time and the Other (R. A. Cohen, Ed. and Trans.). Duquesne University Press.

Marx, K. (1962). Das Kapital. Kritik der Politischen Ökonomie. Erster Band. Marx-Engels-Werke 23 (A. Schnickmann, Ed.). Karl Dietz Verlag.

Marx, K. (2010). Marx \& Engels collected works vol 35: Marx, capital volume I. Lawrence \& Wishart. 
Marx, K- \& Engels, F. (1986). Marx \& Engels collected works vol 28. Lawrence \& Wishart.

McConnell, F. D. (1975). The spoken seen: Film \& the romantic imagination. Johns Hopkins U. Press.

Mitchell, D. T. \& Snyder, S. L. (2003). Narrative prosthesis. Disability and the dependencies of discourse. The University of Michigan Press.

Mulvey, L. (1975). Visual pleasure and narrative cinema. Screen 16(3): 6-18.

Neimann, S. (2015). Evil in modern thought. An alternative history of philosophy. Princeton U. Press.

Neocleous, M. (2005). The monstrous and the dead: Burke, Marx, fascism. University of Wales Press.

Nietzsche, F. (1974). The gay science (W. Kaufmann, Ed., Trans.). Vintage Books.

Nietzsche, F. (2006). Thus spoke Zarathustra. A book for all and none (A. Del Caro \& R. B. Pippin, Eds., A. Del Caro, Trans.). Cambridge University Press.

Norden, M. F. (2007). The 'uncanny' relationship of disability and evil in film and television. In M. F. Norden (Ed.), The changing face of evil in film and television (pp. 125-44). Rodopi.

Plato. (1997). Timaeus. In J. M. Cooper (Ed.), Plato. Complete works (pp. 1224-92). Hackett Pub. Co.

Santilli, P. (2007). Culture, evil, and horror. American Journal of Economics and Sociology 66(1): 173-93.

Scudieri, A. (2019). Plato on evil. In T. Nys \& S. de Wijze (Eds.), The Routledge handbook of the philosophy of evil (pp. 15-29). Routledge.

Smith, A. M. (2004). Impaired visions. The cultural and cinematic politics of blindness in the horror film. In I. Conrich (Ed.), Horror zone. The cultural experience of contemporary horror cinema (pp. 27086). I.B. Tauris.

Sony Pictures India. (2016, Aug 30). See what he sees [Video]. YouTube. https://www.youtube.com/watch?v=_F1I-cxz21M

Wright, A. (2013). Monstrosity: The human monster in visual culture. I.B. Tauris. 